\title{
The Impact of Product Knowledge and Product Involvement to Repurchase Intention for Tupperware Products among Housewives in Surabaya, Indonesia
}

\author{
Priscillia Elsya $^{1^{*}}$ and Ratih Indriyani \\ Department of Management, Faculty of Business and Economics, Petra Christian University, \\ Jl. Siwalankerto 121-131, Surabaya 60236 Indonesia
}

\begin{abstract}
The number of consumers can be used as a measuring tool in determining the company's sales success. Repurchase intention reflects the needs of consumers in repeat purchasing patterns. Factors that can increase repurchase intention are knowledge of products and consumer involvement with products. Product knowledge can increase repurchase intention because with the information about the quality of the product can trigger repeat purchases. Also, product involvement can increase repurchase intention because the consumers can evaluate the products directly and decide to purchase another product that has met their needs This study aims to measure the effect of product knowledge on repurchase intention and the effect of product involvement on repurchase intention on Tupperware products for Surabaya market. The research is using a quantitative approach, and take a sample from housewives who reside in Surabaya. Data are collected through questionnaires distributed to 150 people. Only 102 questionnaires are valid. Then, the data are processed using SPSS. The results show that product knowledge affects repurchase intention and product involvement significantly affects repurchase intention in Tupperware products among housewives in Surabaya, Indonesia.
\end{abstract}

Keywords: Customer product knowledge, customer product involvement, customer repurchase intention.

\section{Introduction}

Along with the rapid growth of the industry in the field of household appliances, consumers increasingly realize the importance of choosing a quality and durable equipment. According to Kertajaya, consumers today are those who determine their purchasing choices with longterm considerations and are more environmentally conscious and health-conscious [1]. That means the increasingly varied consumer's spirit encourages companies producing household appliances to compete in producing their best products so that they are in demand by consumers [2]. Muharam and Soliha explained that the current complex global

* Corresponding author: ranytaa@petra.ac.id 
competition conditions require companies to be able to create the right and quality products for the market, to be able to increase profits by repurchasing consumers [3].

Tupperware is a household product made of plastic, which includes storage containers, serving containers, and some kitchen utensils. Tupperware uses a method to purify black polyethylene pulp (the primary material for making plastics) into plastic material used in various household appliances [4]. The competition in the business world also has an impact on the emergence of similar products in the home industry, including Tupperware. Many companies offer similar products at lower prices, so consumers begin to switch to using other products. Besides, there are also many fake products appearing at lower prices. According to [4], one of the leading causes is the absence of real sanctions for sellers or consumers when using fake products. This encourages companies, in addition to producing quality products, to provide product knowledge to consumers, especially on products that have a direct sales base such as Tupperware plastic materials used in various household appliances [5].

Indonesia is the most significant and biggest market for Tupperware product sales to beat Germany which is the biggest market for Tupperware products. Tupperware sales increased in 2015 but decreased in 2014 and 2015. On the other hand, there was an increase in the number of Tupperware members, who allegedly attracted consumers to make repurchase intentions because they get points to get discounts on future purchases. Even from the same source, it was also stated that many housewives in Indonesia became salespeople from Tupperware products with a total of 250000 salespeople [5].

Product knowledge is the perception of knowledge possessed by consumers of a particular product, including the experience of consumers in using previous products. The existence of product knowledge can build and assist consumers in evaluating a product so that it can feel the value of the product consumed [6]. Product knowledge also includes the entire scope of information stored in consumer memory and can influence the actions to be taken next, including the intention to do repurchase intentions of products that have been previously purchased as a whole [7]. Furthermore, consumers with higher knowledge will be more realistic in choosing products that are in line with their expectations [8].

Regarding product knowledge, Tupperware offers products that have innovative functions and features, for example, the stacking feature that allows consumers to arrange the containers neatly upward without worrying to collapse, nesting features that help consumers save space at home, and modular features that make the kitchen look neater with a beautifully arranged Tupperware containers. Tupperware provides a lifetime guarantee that is the distinguishing characteristic of Tupperware from other similar products [5] Product knowledge for the housewives is about good product quality, expensive prices, lifetime guarantee, and other benefits.

The creation of product knowledge cannot be separated from the involvement of the product itself. Sometimes, many housewives buy Tupperware products to be used both for children's lunch boxes and for everyday uses, but some housewives only buy Tupperware products for display or special moments. Product involvement is a reference that shows the extent to which an individual or customer. It can engage with certain products on a regular basis to encourage interest in repurchase intention in the future.

According to Tommy and Richard, knowledge about a particular product affects repurchase intention [9]. In buying a product, product knowledge is needed to determine the quality of the product. Consumers will feel safer to use if they know the ingredients or the quality of the product. This is interesting to study further because it is based on [10] that product knowledge does not affect consumer purchase intentions. In this case, the consumer does not need sufficient knowledge and information sources in deciding on a purchase. The results of other studies conducted by $[11,10,12]$. Conclude that consumer involvement in the product (product involvement) has a significant effect on repurchase intention. 
This research wants to explore the influence of Tupperware product knowledge on repurchase intention among homemakers in Surabaya. This research also wants to examine product involvement and its effect on repurchase intention.

\section{Literature review}

\subsection{Product knowledge}

Product knowledge can be interpreted as the entire scope of accurate information that is stored in memory and can be used to perba team in making a purchase decision [7]. Peter and Olson explain that product knowledge as various types of knowledge, meaning, and belief is recorded in consumers' memories [8]. Consumers with higher knowledge will be more realistic in choosing products that meet their expectations. The higher the product knowledge in product purchases, can increase the ability of consumers to make choices.

Indicators for product knowledge according to Aertens et al., are subjective knowledge, objective knowledge, and experience knowledge [13]. Subjective knowledge is the level of knowledge consumers have for a product. Objective knowledge is how much information is stored in consumer memory related to the brand, attributes, situation of use, type and class of a product. Also, experience knowledge is additional information obtained on a product after buying and using a product.

\subsection{Product involvement}

Product involvement can be described as a perception held by consumers of the interests of a product category based on the needs, values, and interests of consumers [14]. The high level of consumer attention to a product is called high involvement, while the lower the consumer's attention to a product is called low involvement [15]. Indicators of product involvement, according to Bian and Moutinho are consideration, pleasure, and benefits [14]. Consideration is one's interest in a product category; Pleasure is related to the hedonic value of the product, its ability to provide pleasure, satisfaction, and enjoyment.

\subsection{Repurchase intention}

Repurchase intention is the process of making decisions by consumers after purchasing products offered or needed by consumers [16]. Indicators of repurchase intention according to Jurniati, Rahman and Hafasnudin are transactional interest, referential interest, preferential, and explorative interest [12]. Transactional interest is the interest associated with the tendency of consumers to repurchase a product or brand. Referential interest is the tendency to refer products or brands to relations or relatives so that they participate in buying the product. Preferential interest is the tendency always to choose a product or break as the primary preference when needing a similar product. Explorative interest is the tendency to always look for information about the product or brand to support the positive qualities of the product. 


\section{Hypothesis development}

\subsection{Product knowledge and repurchase intention}

Product attributes that consist of the brand, value, quality, experience using products in the past, as well as information about the product give a role in the process of making repurchase intention [10]. Rehman et al., explain the activity of deciding to buy a product will reopen the memory of the product if the product is questionable [17]. This means that consumers' perceptions and points of view will help in the decision-making process. Customer knowledge of a product will significantly relate to a product purchase. Consumers with higher product knowledge will be more realistic in deciding on purchasing a product [18]. Tommy and Richard explain that consumer knowledge about a product is very influential on repeat purchases [9]. In making repeat purchases, consumers choose and determine the product they want.

$\mathrm{H}_{1}$ : Product knowledge has a positive significant impact on repurchase intention.

\subsection{Product involvement and repurchase intention}

Consumers with a higher level of involvement will strive for greater effort and better understand the information presented about a product [19, 15]. Consumers with high involvement tend to have a willingness to pay attention to product information. This condition will affect consumer behavior in subsequent purchases [19].

Consumer involvement in using products can influence consumers in evaluating repurchases [10]. Lin, Shui, and Chuan explain that consumer involvement will influence the results of consumer decisions [11]. The involvement of the product gives rise to stimulation to consumers over the purchase of a previous product. These stimuli will increase his desire to make further purchases [20]. Product involvement affects consumer sensitivity to prices [21].

$\mathrm{H}_{2}$ : Product involvement has a positive significant impact on repurchase intention.

\section{Research method}

This research uses quantitative methods to examine the causal relationships between variables. The object of this research is housewives in Surabaya. The population of this research is all housewives in Surabaya with a total of 768902 people [22].The sample in this research is 100 housewives obtained using an accidental quota sampling technique and by using the Slovin formula. Data processing in this study uses statistical regression with the application of Statistical Products and Service Solutions (SPSS) 25th edition. Data analysis is done by testing the validity and reliability. Data are tested using classic assumptions which consisted of tests of normality and heteroscedasticity. Hypothesis testing is done by t-test.

\section{Results}

\subsection{Validity and reliability test}

The validity test results show that the significant value of the correlation of each item of product knowledge variable questions is less than 0.05 . So, it can be concluded that all statement items on the product knowledge variable are valid. Meanwhile, the significant value of the correlation of each item of variable product involvement statement is then 0.05. So, it can be concluded that all statement items on product improvement variables are valid. 
The test results show that the significant value of the correlation of each repurchase intention variable statement item is less than 0.05 . So, it can be concluded that all items of statement on the product involvement variable are valid.

The reliability test in this research observes the Cronbach Alpha. If Cronbach Alpha > 0.60 , then the variable is declared reliable. The reliability test results find that the product knowledge, product innovation and repurchase intention variables have the Cronbach Alpha of more than 0.60 , so all items of statements of the research variables are stated to be reliable.

\subsection{Classical assumption test}

\subsubsection{Normality test}

For the normality test, the detection of residual normality is carried out by the KolmogorovSmirnov test. Kolmogorov-Smirnov test results showed as value of significance $>0.05$ $(\alpha=5 \%)$ so that it can be concluded that the residual regression model is normally distributed.

\subsubsection{Multicollinearity test}

The results showed that product knowledge (X1), product involvement (X2) had tolerance values of 0.319 and 0.319 which showed greater tolerance values of 0.10 and VIF values of 3.138 and 3.138 respectively, indicating tolerance values of less than 10 . Therefore it can be said that the independent variable product knowledge (X1), product involvement (X2) there is no multicollinearity.

\subsubsection{Heteroscedasticity test}

The heteroscedasticity test shows the significance of the correlation which all the variables $>0.05$, it can be concluded that there was no heteroscedasticity in the regression model.

\subsubsection{Hypothesis test}

An analysis of multiple linear regression was performed to determine whether the variable product knowledge (X1) and product involvement (X2) affect the repurchase intention (Y) of Tupperware products for housewives in Surabaya.

The linear regression equation is stated as follows:

$$
\mathrm{Y}=2.535+0.139 \mathrm{X}_{1}+0.666 \mathrm{X}_{2}
$$

Based on the equation above, it can be explained that:

- $\alpha=$ constant $=2.535$ This means that if the product knowledge (X1) and product involvement $(\mathrm{X} 2)=0$, then the re-intention of the intention $(\mathrm{Y})$ will be 2.535 .

- $\quad \mathrm{b} 1=$ regression coefficient for $\mathrm{X} 1=0.139$. This means that if the product knowledge increases by 1 then the effect on repurchase intention will increase by 0.139 .

- $\quad \mathrm{b} 2=$ regression coefficient for $\mathrm{X} 2=0.666$. This means that if the product knowledge increases by 1 then the effect on repurchase intention will increase by 0.666 .

\subsubsection{The t test and F test}

Based on the $\mathrm{F}$ test it is known that the $\mathrm{F}$ value of 65.366 with a significance level of less than 0.05 then the regression model used is fit.

Based on the t-test results table obtained:

i. Product knowledge influences repurchase intention because t-count $>\mathrm{t}$-table is 2.445 , higher than 1.9844 . 
ii. Product involvement has a significant effect on repurchase intention because t-count $>$ t-table is 5.210, higher than 1.9844 .

\section{Discussion}

The results of this study are product knowledge and product involvement have a significant effect on repurchase intention. Product knowledge is the knowledge that is owned by consumers about a product. Product knowledge possessed by housewives about Tupperware products is that the quality is durable, does not leak easily, is durable. This makes homemakers want to repurchase Tupperware products. In addition to its quality, design and color, it is also attractive to homemakers. The results of this study are consistent with statements from [9] who argue that product knowledge about a product is very influential on repurchase intention.

Product involvement is the involvement of consumers in the product, especially Tupperware products to the interests based on the needs, values, and interests of consumers. The results of this study are consistent with statements from [20] which state that the existence of good stimuli received by consumers on products purchased will increase their desire to make further purchases.

\section{Conclusion}

The results of this study are product knowledge and product involvement significantly influence repurchase intention. Suggestions that can arise from this research are expected by Tupperware producers to provide information about products by utilizing internet media because with the internet, consumers can more easily obtain information about Tupperware products. This is to answer the needs of consumers to obtain precise and fast information. The company should provide consumer education to better understand the type of product and the use of Tupperware. This is done so that consumers know the function of Tupperware variations so that consumers can utilize Tupperware products optimally. It is hoped that marketers can better introduce the variety and function of Tupperware products to consumers through social media, exhibitions, sales forces, and so on. This step aims to introduce and inform consumers about product variants and functions.

\section{References}

1. H. Kertajaya, Marketing Plus 2000. Jakarta: Gramedia (2002). [in Bahasa Indonesia]. https://books.google.co.id/books?id=NmUHCv-COkMC\&dq=(2002)

2. G. Wahyuni, G. Suparna, E-jurnal Manajemen Universitas Udayana, 3,4:10221034(2014). https://ojs.unud.ac.id/index.php/Manajemen/article/view/7540

3. W. Muharam, E. Soliha, Proceeding SENDI_U, p.755-762 (2017). https://www.unisbank.ac.id/ojs/index.php/sendi_u/article/view/5100

4. A. Ika, Studi: tingkat pemalsuan barang di Indonesia di angka mengkhawatirkan. [Study: the level of counterfeiting of goods in Indonesia is alarming], [Online] from https://money.kompas.com/read/2017/02/21/080000926/studi.tingkat.pemalsuan.baran g.di.indonesia.di.angka.mengkhawatirkan (2017). [Accessed on June 26, 2019]. [in Bahasa Indonesia].

5. Tupperware. Tentang kami [About us], [Online] from https://www.tupperware.co.id/tentang-kami (2018). [Accessed on 17 Februari 2019]. [in Bahasa Indonesia]. 
6. S. Jayachandran, K. Hewett, P, Kaufman Journal of the Academy of Marketing Science 2,3:219-233(2004)

https://journals.sagepub.com/doi/10.1177/0092070304263334

7. U. Sumarwan. Perilaku konsumen: Teori dan penerapannya dalam pemasaran [Consumer behavior: Theory and its application in marketing]. Bogor: PT. Ghalia Indonesia (2011). [in Bahasa Indonesia]. http://publikasi.mb.ipb.ac.id/?p=73

8. J.P. Peter, J.C. Olson, Consumer Bahavior and Marketing Strategy. USA: McGraw Hill (2010).

http://www.academia.edu/download/43639258/Consumer_Behaviour_Notes.pdf

9. S.M. Tommy, A. Richard. Pengaruh brand image dan product knowledge terhadap purchasing intention. kasus kosmetik merk " $X$ ". [The influence of brand image and product knowledge on purchasing intention. "X" brand cosmetic case.]. [Research], University of Tarumanegara, Jakarta (2012). [in Bahasa Indonesia]. http://repository.untar.ac.id/289/

10. O. Akir, M.N. Othman. IEEE Symposium on Industrial Electronics and Applications (ISIEA) (2010). https://ieeexplore.ieee.org/abstract/document/5679462/

11. Y. Lin, C.C. Shui, S.H. Chuan. African Journal of Business Management, 5,14:5910 5919(2011).

http://www.academicjournals.org/app/webroot/article/article1380724902_Lin\%20et\% 20al.pdf

12. Jurniati, L. Rahman, Hafasnudin, Jurnal Perspektif Manajemen dan Perbankan, 8,3:137-157(2017). [in Bahasa Indonesia]. http://www.jurnal.unsyiah.ac.id/JPMP/article/view/10195

13. J. Aertsens, K. Mondelaers, W. Verbeke, J. Buysse, G.V, Huylenbroeck. British Food Journal, 113,11:1353-1378(2011). https://www.emeraldinsight.com/doi/abs/10.1108/00070701111179988

14. X. Bian, L. Moutinho, European Journal of Marketing, 45,1-2:191-216(2011). https://www.emeraldinsight.com/doi/abs/10.1108/03090561111095658

15. L. Lin, C. Chen, Journal of Consumer Marketing, 23,5:248-265(2007). https://www.emeraldinsight.com/doi/abs/10.1108/07363760610681655

16. B. Zeki, International Journal of Business and Social Science, 6,10:55-63(2015). https://www.researchgate.net/profile/Zeki_Bulut/publication/294889763_Determinant s_of_Repurchase_Intention_in_Online_Shopping_A_Turkish_Consumer's_Perspectiv e/links/56c5a30908aeeeffa9e7a686/Determinants-of-Repurchase-Intention-in-OnlineShopping-A-Turkish-Consumers-Perspective.pdf

17. R. Shafiq, I. Raza, M.Z. Rehman, African Journal of Business Management, 5,26:10577-10585(2011).

http://citeseerx.ist.psu.edu/viewdoc/download?doi=10.1.1.1008.4773\&rep=rep1\&type $=\mathrm{pdf}$

18. E. Erida, A.S. Rangkuti, Journal Of Business Studies And Mangement Review, 1,1:26-32(2017). https://www.online-journal.unja.ac.id/jbsmr/article/view/3919

19. T.L. Baker, J.B. Hunt, L.L Scribner, Journal of Marketing Theory and Practice, 10,4:45-57(2002).

https://www.tandfonline.com/doi/abs/10.1080/10696679.2002.11501925

20. T. Curtis, R. Abratt. P. Dion, D.I. Rhoades, Customer satisfaction, loyalty and repurchase: Some evidence from apparel consumers. Reviews of Business, 32,1:4757(2011). https://commons.erau.edu/db-management/20/

21. A. Aypar, H. Bahman, International Journal of Engineerings and Applied Science, 17:515-532(2018). https://dergipark.org.tr/ulikidince/issue/38166/434866

22. Badan Pusat Statistik. Rata-rata anggota rumah tangga per kecamatan dalam Surabaya dalam angka. [Average household members per sub-district in Surabaya in 
numbers]. [Online] from https://surabayakota.bps.go.id/publication/download.html (2017). [Accessed on 17 February 2019]. [in Bahasa Indonesia].

23. Y.F. Huang, H.S. Dang, Europian Journal of Business and Management. 6,36:186196(2014).

http://citeseerx.ist.psu.edu/viewdoc/download?doi=10.1.1.735.2673\&rep=rep $1 \&$ type $=$ $\underline{\mathrm{pdf}}$

24. D.A. Aaker, K.L. Keller, Journal of Marketing, 54,27-41(1990). https://www.jstor.org/stable/1252171

25. D. Retnaningrum. Indonesia pasar terbesar penjualan tupperware lampaui Jerman. [Indonesia is the biggest sales market tupperware exceed Germany]. [Online] from http://www.satuharapan.com/read-detail/read/indonesia-pasar-terbesar-penjualantupperware-lampaui-jerman (2015). [Accessed on 26 Juni 2019] [in Bahasa Indonesia].

26. Topbrandaward. Kategori produk rumah tangga: plastic container, [Household product categories: plastic container]. [Online] from https://www.topbrandaward.com/top-brandindex/?tbi_index=\%20Top\%20Brand\&tbi_year=2018 (2018). [Accessed on 17 Februari 2019] [in Bahasa Indonesia]. 